Annals of Warsaw University of Life Sciences - SGGW

Land Reclamation No 50 (2), 2018: 171-182

(Ann. Warsaw Univ. of Life Sci. - SGGW, Land Reclam. 50 (2), 2018)

\title{
Static load test curve $(Q-s)$ conversion in to pile of different size
}

\section{ZYGMUNT MEYER, KAMIL STACHECKI}

Faculty of Civil Engineering and Architecture, West Pomeranian University of Technology Szczecin, Poland

\begin{abstract}
Static load test curve (Q-s) conversion in to pile of different size. In the work authors analysed possibility of obtaining static load tests curve for a pile in case of changed diameter, using load curve based on results of static load tests for given diameter. In calculation analysis authors used Meyer-Kowalów (M-K) method. A mathematical description was shown of determining new M-K curve for a pile with changed diameter, taking as a basis original M-K curve obtained from static load tests. Then an example of calculations is presented in which parameters of $\mathrm{M}-\mathrm{K}$ model for a new curve were determined. Simulation calculations were carried out in the original computer program, the results of which includes load curves for piles with different diameters and relations between diameter changes, limit load capacity and settlement of a pile.
\end{abstract}

Key words: pile, static load curve interpretation, limit load capacity of a pile, pile settlement, M-K method

\section{INTRODUCTION}

The aim of this study is to analyze possibility of creating static load curve for a pile in the case of diameter changes. The scope of work includes: mathematical description of phenomenon, preparing relations which would allow to determine parameters for Meyer-Kowalów curve for a changed diameter of a pile, then presenting calculation procedures and example of calculation of curve changes in the case of diameter changes.

Issue of determining dependency between static load tests $\left\{S_{i}, N_{i}\right\}$ and limit loads capacity is still a problem. We can distinguish solutions described by: Gwizdała, Chin, Mazurkiewicz, Meyer and Kowalów, Decourt, and also a method of calculations according to Eurocode 7. Methods used in engineering practice are presented among others in work of Gwizdała (2010), Szmechel (2014), Meyer and Szmechel (2015), Meyer (2017). Choice of specific approach depends on method of calculations and degree of construction safety. In Figure 1 is shown an example of dimensioning of a pile using methods listed above for an average soil conditions.

Settlement-load curve $s(N)$ for small loads is linear, and it's mathematical description can be obtained from linear soil mechanics. For larger loads curve $s(N)$ is distinctly non-linear, it has two asymptote diagonal and vertical (Fig. 2).

One of the proposals for a full description of static load curve was presented by Meyer and Kowalów (2010), which was used among others by Szmechel (2014), Meyer and Żarkiewicz (2015), Meyer (2017), Żarkiewicz (2017) to determine limit load capacity of pile skin and toe 


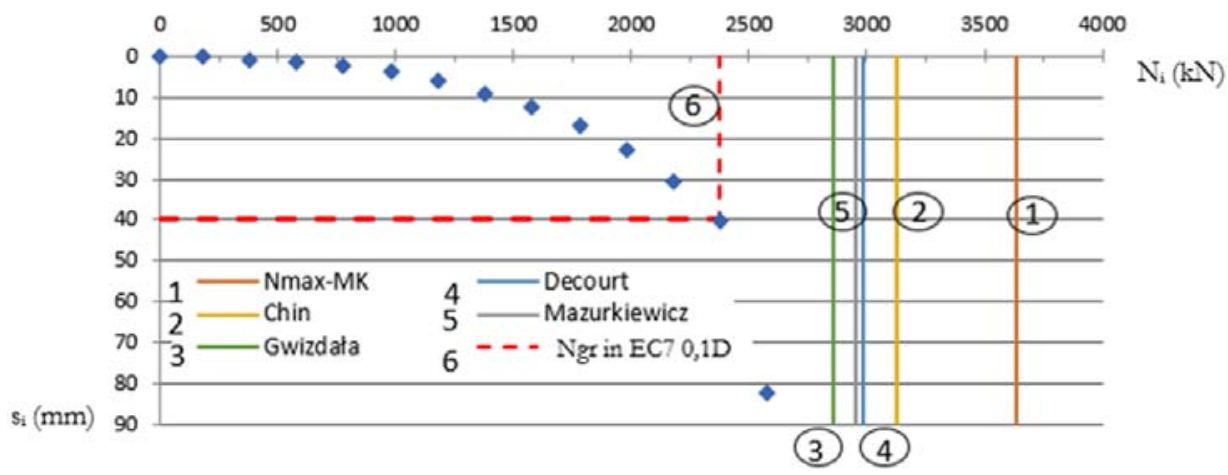

FIGURE 1. Load capacity of a pile determined using different methods (Szmechel 2014)

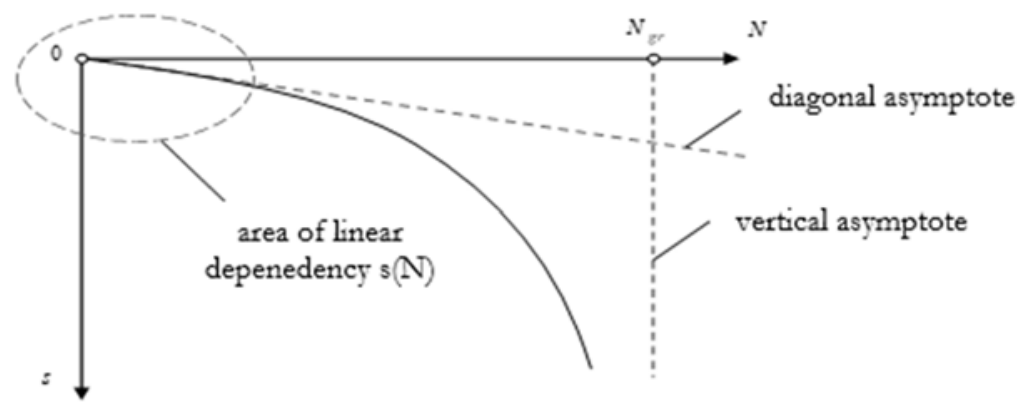

FIGURE 2. Characteristic asymptotes limiting curve for static load test of a pile (Meyer 2017)

and to predict settlement based on static load tests. In the further part of the paper this curve is called M-K curve. In the following part of work M-K method was used in calculation analysis.

Following assumptions were applied in $\mathrm{M}-\mathrm{K}$ method, the full range equation:

$s(N)=C \cdot N_{g r} \cdot \frac{\left(1-\frac{N}{N_{g r}}\right)^{-\kappa}-1}{\kappa}$

and location of asymptotes:

$\lim _{N \rightarrow 0} s(N)=C ; \lim _{N \rightarrow N_{g r}} s(N)=\infty$

settlement-load dependency (Fig. 3) can be calculated then as follows: be calculated then as follows:

$N_{1}(s)=N_{g r 1} \cdot\left[1-\left(1+\frac{\kappa_{1} \cdot s}{C_{1} \cdot N_{g r 1}}\right)^{-\frac{1}{\kappa_{1}}}\right]$

where:

$s-$ pile settlement (m);

$N$ - force in the pile $(\mathrm{kN})$;

$N_{g r}$ - limit load capacity $(\mathrm{kN})$;

$k$ - parameter indicating the proportions between resistances of pile (-).

$N_{2}(s)=N_{g r 2} \cdot\left[1-\left(1+\frac{\kappa_{2} \cdot s}{C_{2} \cdot N_{g r 2}}\right)^{-\frac{1}{\kappa_{2}}}\right]$

$$
T(s)=N_{2}(s)-N_{1}(s)
$$




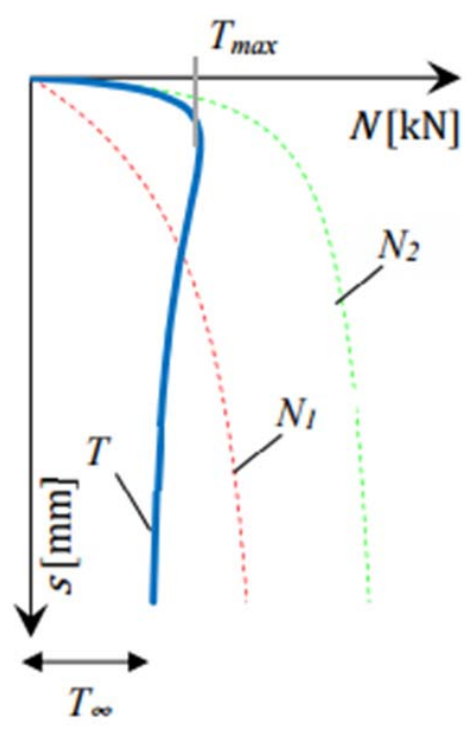

FIGURE 3. Example of settlement-load curves (Żarkiewicz 2017)

where:

$N_{g r 1} \quad-$ limit load capacity of toe $(\mathrm{kN})$;

$N_{g r 2} \quad$ - limit load capacity of toe and skin $(\mathrm{kN})$;

$\kappa_{1}, \kappa_{2}$ - parameters that indicate the proportions between base resistance and skin resistance of pile (-);

$C_{1}, C_{2}-$ parameters that can be compared to inverse Winkler parameter for elastic soil (mm/MN).

Paramaters of M-K model can be calculated using statistical methods, as presented by Szmechel (2014), Meyer and Szmechel (2015), Meyer and Żarkiewicz (2015), Żarkiewicz (2017). Applying the condition of least square method for theoretical curve, best fit to results from static load tests gives:

$$
\delta_{j}^{2}=\sum\left(s_{i}-s_{i}^{c a l}\right)^{2}=\min
$$

\section{MATERIAL AND METHODS}

According to linear elasticity theory (Fig. 4) for a single pile in a soil body we get the following dependence, described by Meyer (2010):

$$
\begin{aligned}
& s=\frac{4}{\pi} \cdot \frac{N_{1}}{E_{q} \cdot D} \\
& s=2 \cdot(1+v) \cdot \frac{\tau}{E_{t}} \cdot l
\end{aligned}
$$

where:

$E_{q}, E_{t}$ - elasticity moduli $\left(\mathrm{kN} / \mathrm{m}^{2}\right)$;

$D$ - diameter of a pile (m);

$v \quad-$ Poisson's parameter (-);

$\tau \quad-$ shear stresses on the pile skin $\left(\mathrm{kN} / \mathrm{m}^{2}\right)$;

$l \quad$ - linear distance of shear stress impact (m),

$\sigma_{1} \quad$ - normal stresses under the toe $\left(\mathrm{kN} / \mathrm{m}^{3}\right)$

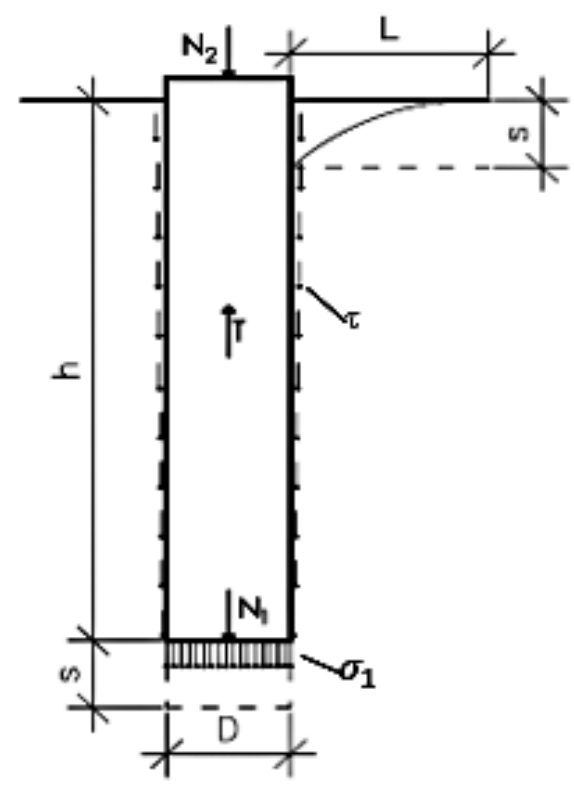

FIGURE 4. Scheme of pile settlement 
because skin resistance is given as:

$T=\pi D h \cdot \tau$

where:

$h$ - length of pile in soil (m).

we get the following relationships:

$T=\frac{\pi D h}{2(1+v)} \cdot E_{t} \cdot \frac{s}{l}$

where:

$T$ - force on pile skin generated by shear stresses $(\mathrm{kN})$.

$N_{1}=\frac{\pi}{4} \cdot E_{q} \cdot s \cdot D$

and furthermore:

$\frac{T}{N_{1}}=\frac{2}{1+v} \cdot \frac{E_{t}}{E_{q}} \cdot \frac{h}{l}$

The second assumption that we introduce is the equalization of normal stresses in the ground at the toe of a pile (Meyer 2010):

$$
\frac{T}{N_{1}}=\frac{l^{2}}{D^{2}}
$$

After substitituon relevant formula we obtain:

$$
l=D \cdot \sqrt[3]{\frac{2}{1+v} \cdot \frac{E_{t}}{E_{q}}} \cdot \sqrt[3]{\frac{h}{D}}
$$

As the result for small load-deformation we have:

$$
\frac{T}{N_{1}}=\left(\frac{2}{1+v} \cdot \frac{E_{t}}{E_{q}} \cdot \frac{h}{D}\right)^{2 / 3}
$$

The third stage of approximation are relations between $\mathrm{M}-\mathrm{K}$ curve param- eters for small load displacements. We have:

$N_{2}=\frac{s}{C_{2}} ; \quad N_{1}=\frac{s}{C_{1}} ; \quad T=\frac{s}{C_{t}}$

$C_{t}-$ parameter that can be compared to inverse Winkler parameter for elastic soil (mm/MN).

After substititing the above dependencies into basic relation:

$N_{2}=N_{1}+T$

we get relations appropriate for practical calculations:

$\frac{1}{C_{2}}=\frac{1}{C_{1}}+\frac{1}{C_{t}}$

$\frac{T}{N_{1}}=\frac{C_{1}}{C_{t}}=\left(\frac{2}{1+v} \cdot \frac{E_{t}}{E_{q}} \cdot \frac{h}{d}\right)^{2 / 3}$

where:

$d$ - diameter of a pile (m).

It allows to obtain relations between constants $C$ :

$C_{t}=\frac{C_{1}}{\left(\frac{2}{1+v} \cdot \frac{E_{t}}{E_{q}} \cdot \frac{h}{D}\right)^{2 / 3}}$

$C_{t}=C_{2} \cdot\left[1+\left(\frac{2}{1+v} \cdot \frac{E_{t}}{E_{q}} \cdot \frac{h}{D}\right)^{\frac{2}{3}}\right]$

For simplification it is convenient to enter $U$ parameter, as a material constant of the soil:

$U=\left(\frac{2}{1+v} \cdot \frac{E_{t}}{E_{q}}\right)^{\frac{2}{3}}$

where:

$U-$ material constant of soil (-). 
Therefore we recieve:

$$
\frac{C_{1}}{C_{t}}=\frac{T}{N_{1}}=U \cdot\left(\frac{h}{d}\right)^{\frac{2}{3}}
$$

and

$$
\begin{aligned}
& \frac{C_{1}}{C_{2}}=1+U \cdot\left(\frac{h}{d}\right)^{\frac{2}{3}} \\
& \frac{C_{t}}{C_{2}}=\frac{1+U \cdot\left(\frac{h}{d}\right)^{\frac{2}{3}}}{U \cdot\left(\frac{h}{d}\right)^{\frac{2}{3}}}
\end{aligned}
$$

One of the aims of this work is determining possibility of obtaining new $\mathrm{M}-\mathrm{K}$ curve in case of a diameter changes. We assume that the original curve is described by pile geometry $h^{(0)} ; D^{(0)}$ and the results of static load tests $\left\{N_{i}, S_{i}\right\}$. Based on these data we want to determine parameters for new $\mathrm{M}-\mathrm{K}$ curve in the same soil but with changed pile geometry $h^{(1)} ; D^{(1)}$.

On the base of results of static load test we determine parameters of $\mathrm{M}-\mathrm{K}$ model:

$C_{2}^{(0)} ; \kappa_{2}^{(0)} ; N_{g r 2}^{(0)}$

then we calculate according to Żarkiewicz (2017):

$C_{1}^{(0)}=C_{2}^{(0)} \cdot\left(1+\kappa_{2}^{(0)}\right)^{2}$

and

$\kappa_{1}^{(0)}=0.82 \cdot \kappa_{2}^{(0)}$

In order to calculate $N_{g r 1}^{(0)}$ we need to determine value of $q_{c}$. From linear elasticity theory we have:

$$
C_{1}=\frac{4}{\pi} \cdot \frac{1}{E_{q} \cdot D}
$$

In practical calculations we usually use aproximate relation (Szmechel 2014):

$$
C_{1}=\frac{1}{\pi} \cdot \frac{1}{\text { const } \cdot q_{c} \cdot D}
$$

where:

const $=2-4$

$q_{c}$ - stresses created by tow resistance $\left(\mathrm{kN} / \mathrm{m}^{2}\right)$.

We accept in practical calculations following expression according to Szmechel (2014):

$C_{1}=\frac{1}{3 \pi \cdot q_{c} \cdot D}$

therefore for state " 0 "

$q_{c}=\frac{1}{3 \pi \cdot C_{1}^{(0)} \cdot D^{(0)}}$

and above value of $q_{c}$ is taken for further calculations. After that we can calculate:

$$
N_{g r 0}=\frac{\pi D^{(0)^{2}}}{4} \cdot q_{c}
$$

and

$$
N_{g r 1}{ }^{(0)}=\frac{4}{3 \pi^{2}} \cdot q_{c}^{\left(\frac{1}{4}\right)} \cdot\left(\frac{H}{D^{(0)}}\right)^{\left(\frac{1}{3}\right)} \cdot N_{g r 0}
$$

After obtaining all parameters of M-K model in state " 0 ":

$C_{1}^{(0)} ; C_{2}^{(0)} ; \kappa_{1}^{(0)} ; \kappa_{2}^{(0)} ; N_{g r 1}^{(0)} ; N_{g r 2}^{(0)}$ 
we begin calculations with determining material constant $U$ for given soil.

$$
\begin{aligned}
& \frac{C_{1}^{(0)}}{C_{2}^{(0)}}=1+U \cdot\left(\frac{h^{(0)}}{D^{(0)}}\right)^{\frac{2}{3}} \\
& U=\frac{\frac{C_{1}^{(0)}}{C_{2}^{(0)}}-1}{\left(\frac{h^{(0)}}{D^{(0)}}\right)^{\frac{2}{3}}}=\mathrm{const}
\end{aligned}
$$

After that we calculate $E_{q}$ :

$$
E_{q}=\frac{4}{\pi D_{0} \cdot C_{1}^{(0)}}
$$

From formula (23) we can determine:

$$
C_{t}^{(0)}=\frac{2(1+v)}{\pi D^{(0)} \cdot E_{t}} \cdot \frac{l}{h^{(0)}}
$$

$E_{t}=\frac{2(1+v) \cdot U^{\frac{3}{2}}}{\pi \cdot C_{1}^{(0)} \cdot D^{(0)}}$

$\frac{E_{t}}{E_{q}}=\frac{1+v}{2} \cdot U^{\frac{3}{2}}$

In this way we obtain relations between M-K curve parameters for " 0 "state, and mechanical parameters of soil:

$E_{q}=E_{q}^{(0)}=\frac{4}{\pi D^{(0)} \cdot C_{1}^{(0)}}$

and next

$$
E_{t}=\frac{2(1+v)}{\pi D_{0} \cdot C_{1}^{(0)}} \cdot U^{\frac{3}{2}}
$$

Determining M-K curve parameters in case of a diameter changes may mean:

- for homogenous soil we change $D=D^{(1)} ; h=h^{(1)}$;

- for layered soil we change $D=D^{(1)}$, because there is an assumption that along pile skin soil resistance does not change.

Proposing a method of converting statitc load curve we made an assumtpion, that parameter $U$ is constant value independent of the pile diamater. From formula (35) we obtain the relation between state " 0 " and state " 1 ".

$$
\frac{\frac{C_{1}^{(0)}}{C_{2}^{(0)}}-1}{\left(\frac{h^{(0)}}{D^{(0)}}\right)^{\frac{2}{3}}}=\frac{\frac{C_{1}^{(1)}}{C_{2}^{(1)}}-1}{\left(\frac{h^{(1)}}{D^{(1)}}\right)^{\frac{2}{3}}}
$$

In this equation we have two unknowns $C_{1}{ }^{(1)}$ and $C_{2}{ }^{(1)}$. Calculating $C_{1}^{(1)}$ requires knowing $E_{q}$ under the toe of a pile. In general case the elasticity modulus $\left(E_{q}\right)$ at the toe depend on settlement and therefore upon the change of soil compaction. It means that:

$E_{q}^{(1)}=E_{q}(s)$

Above relations in approximate calculations is often replaced with:

$C_{1}=\frac{4}{\pi} \cdot \frac{1}{E_{q} \cdot D}$

it leads to a dependencies:

$E_{q}^{(1)}=E_{q}^{(0)}$ 
what it means is that the density index remains unchanged. So we have:

$C_{1}^{(1)}=C_{1}^{(0)} \cdot \frac{D^{(0)}}{D^{(1)}}$

and

$$
C_{2}^{(1)}=C_{1}^{(0)} \cdot \frac{\frac{D^{(0)}}{D^{(1)}}}{1+\left(\frac{C_{1}^{(0)}}{C_{2}^{(0)}}-1\right) \cdot\left(\frac{h^{(1)}}{h^{(0)}} \cdot \frac{D^{(0)}}{D^{(1)}}\right)}
$$

Further analysis of results requires using following relations Żarkiewicz (2017):

$$
\begin{aligned}
& \frac{C_{1}}{C_{2}}=\left(1+\alpha \cdot \kappa_{2}\right)^{2} \\
& {\left[\sqrt{\frac{C_{1}^{(0)}}{C_{2}^{(0)}}}-1\right]=\alpha \cdot \kappa_{2}^{(0)}}
\end{aligned}
$$

where:

$\alpha-$ parameter of adhesion (-),

$$
\kappa_{2}^{(1)}=\kappa_{2}^{(0)} \cdot \frac{\sqrt{\frac{C_{1}^{(1)}}{C_{2}^{(1)}}}-1}{\sqrt{\frac{C_{1}^{(0)}}{C_{2}^{(0)}}}-1}
$$

and next according to Żarkiewicz (2017):

$$
\kappa_{1}^{(1)}=0.82 \cdot \kappa_{2}^{(1)}
$$

Another element is calculating limit load capacity $N_{g r 1}{ }^{(1)}$ and $N_{g r 2}{ }^{(1)}$. For the calculations we use formula (Żarkiewicz 2017):

$$
\frac{N_{g r 1}^{(0)} \cdot C_{1}^{(0)}}{N_{g r 2}^{(0)} \cdot C_{2}^{(0)}}=1+\beta \cdot\left(\frac{H}{D}\right)^{\left(\frac{1}{3}\right)} \cdot \sqrt{\kappa_{2}}
$$

where:

$\beta$ - parameter that takes into account the local interaction of pile and soil (-),

therefore

$$
\begin{aligned}
& {\left[\frac{N_{g r 1}^{(0)} \cdot C_{1}^{(0)}}{N_{g r 2}^{(0)} \cdot C_{2}^{(0)}}-1\right] \cdot \frac{1}{\left(\frac{H}{D^{(0)}}\right)^{\left(\frac{1}{3}\right)} \cdot \sqrt{\kappa_{2}^{(0)}}}=} \\
& =\left[\frac{N_{g 1}^{(1)} \cdot C_{1}^{(1)}}{N_{g r 2}^{(1)} \cdot C_{2}^{(1)}}-1\right] \cdot \frac{1}{\left(\frac{H}{D^{(1)}}\right)^{\left(\frac{1}{3}\right)} \cdot \sqrt{\kappa_{2}^{(1)}}}
\end{aligned}
$$

and after rearranging we obtain:

$$
\begin{aligned}
& \frac{N_{g r 1}^{(1)} \cdot C_{1}^{(1)}}{N_{g r 2}^{(1)} \cdot C_{2}^{(1)}}-1= \\
& =\frac{\left(\frac{H}{D^{(1)}}\right)^{\left(\frac{1}{3}\right)} \cdot \sqrt{\kappa_{2}^{(1)}}}{\left(\frac{H}{D^{(0)}}\right)^{\left(\frac{1}{3}\right)} \cdot \sqrt{\kappa_{2}^{(0)}}} \cdot\left[\frac{N_{g r 1}^{(0)} \cdot C_{1}^{(0)}}{N_{g r 2}^{(0)} \cdot C_{2}^{(0)}}-1\right]
\end{aligned}
$$

In the calculation of toe resistance is convenient to use following relation:

$$
N_{g r 1}^{(0)}=\mathrm{const} \cdot \frac{\pi \cdot\left[D^{(0)}\right]^{2}}{4} \cdot q_{c}
$$


After determining value of $q_{c}$ from formula (31), we can calculate $N_{g r 1}{ }^{(1)}$.

$N_{g r 1}^{(1)}=N_{g r 1}^{(0)} \cdot\left(\frac{D^{(1)}}{D^{(0)}}\right)^{2}$

Last parameter is $N_{g r 2}{ }^{(1)}$, which we calculate based upon a formula (54).

\section{RESULTS AND DISCUSSION}

For known parameters of a concrete pile in state " 0 ".

$H=16 \mathrm{~m} ; D^{(0)}=0.4 \mathrm{~m} ;$

$C_{2}^{(0)}=0.004 \frac{\mathrm{m}}{\mathrm{MN}} ; N_{g r 2}^{(0)}=2,800 \mathrm{kN} ;$

$\kappa_{2}^{(0)}=1.4$

and

$C_{1}^{(0)}=0.023 \frac{\mathrm{m}}{\mathrm{MN}} ; \kappa_{1}^{(0)}=1.12 ; N_{g r 1}^{(0)}=$

$=1,447 \mathrm{kN} ; E_{q}^{(0)}=138.16 \frac{\mathrm{MN}}{\mathrm{m}^{2}}$

TABLE 1. Results of the calculation of M-K curve parameters in case of the change of diameter $(D)$

\begin{tabular}{|c|c|c|c|}
\hline$D(\mathrm{~m})$ & 0.3 & 0.4 & 0.5 \\
\hline$H(\mathrm{~m})$ & 16 & 16 & 16 \\
\hline$H / D(-)$ & 53.333 & 40.000 & 32.000 \\
\hline$C_{1}(\mathrm{~m} / \mathrm{MN})$ & 0.031 & 0.023 & 0.018 \\
\hline$\kappa_{1}(-)$ & 1.313 & 1.12 & 1.032 \\
\hline$N_{\mathrm{gr} 1}(\mathrm{kN})$ & 693 & 1231 & 1924 \\
\hline$C_{2}(\mathrm{~m} / \mathrm{MN})$ & 0.005 & 0.004 & 0.003 \\
\hline$\kappa_{2}(-)$ & 1.601 & 1.400 & 1.259 \\
\hline$N_{\mathrm{gr} 2}(\mathrm{kN})$ & 1671 & 2800 & 4178 \\
\hline$C_{1} / C_{2}(-)$ & 6.766 & 5.760 & 5.102 \\
\hline$N_{g \mathrm{gr} 1} / N_{\mathrm{gr} 2}(-)$ & 0.414 & 0.440 & 0.460 \\
\hline
\end{tabular}

which were taken from calculations (Szmechel 2014). Using relations described by formulas (42)-(56) parameters in state " 1 " for changed diameter were calculated. Results are presented in Table 1.

Computer program was created which allows for calculations. In Figures 5 and 6 curves were obtained according to formulas (3)-(5).

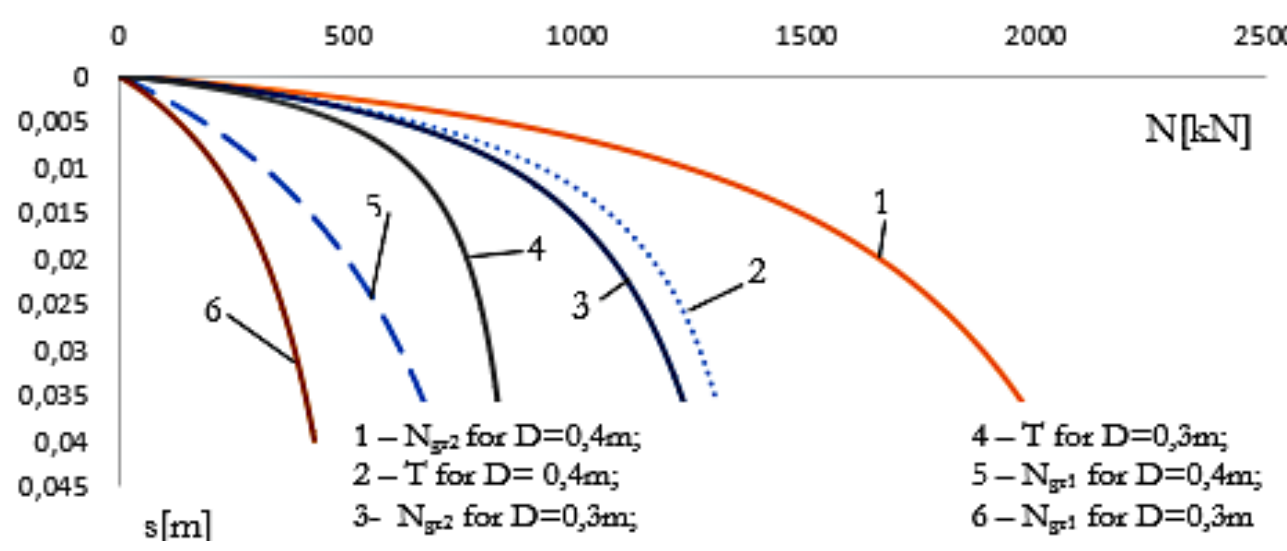

FIGURE 5. Comparison of M-K curve for $D=0.4 \mathrm{~m}$ (state "0") and $D=0.5 \mathrm{~m}$ (state "1") 


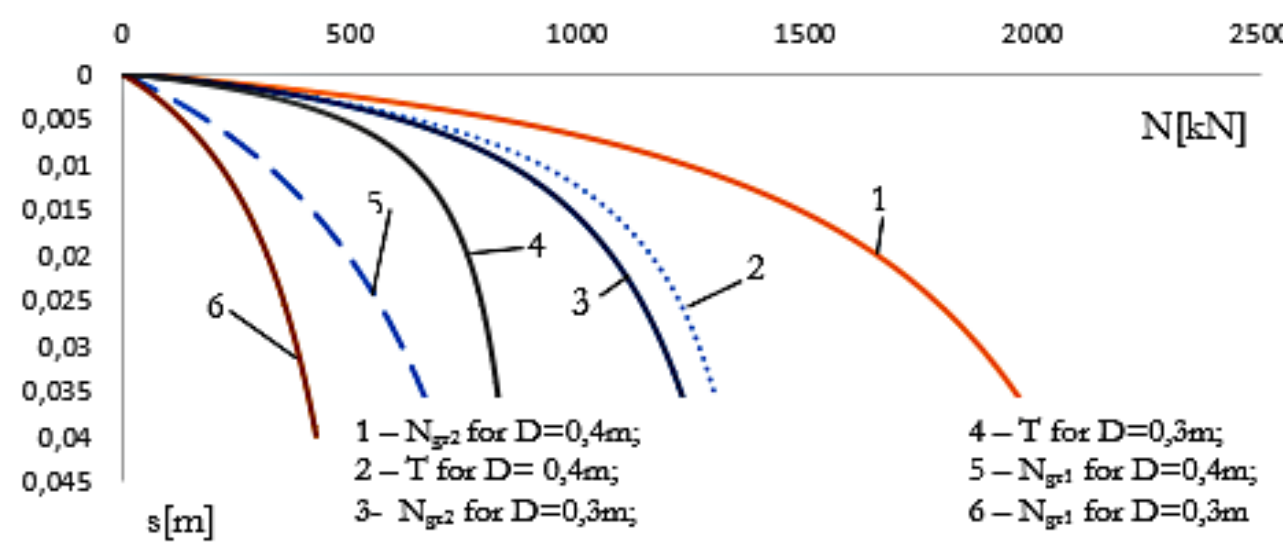

FIGURE 6. Comparison of M-K curve for $D=0.4 \mathrm{~m}$ (state "0") and $D=0.3 \mathrm{~m}$ (state " 1 ”)

It was also analyzed how the parameters of the M-K curve variation follows the change of diameter. The results are given in Table 2 and Figure 7.

Settlement was calculated using for- The results are given in Tables 3 and 4 mula (1). As a safety factor for limit load and Figures 8 and 9.

TABLE 2. Change of the load capacity $N_{g r 2}$ depending on the change of diameter $(D)$

\begin{tabular}{|c|c|c|c|c|c|c|c|c|c|c|c|}
\hline$N_{g r 2}(\mathrm{kN})$ & 1671 & 1876 & 2092 & 2318 & 2554 & 2800 & 3056 & 3322 & 3598 & 3883 & 4178 \\
\hline$D(\mathrm{~m})$ & 0.3 & 0.32 & 0.34 & 0.36 & 0.38 & 0.4 & 0.42 & 0.44 & 0.46 & 0.48 & 0.5 \\
\hline
\end{tabular}

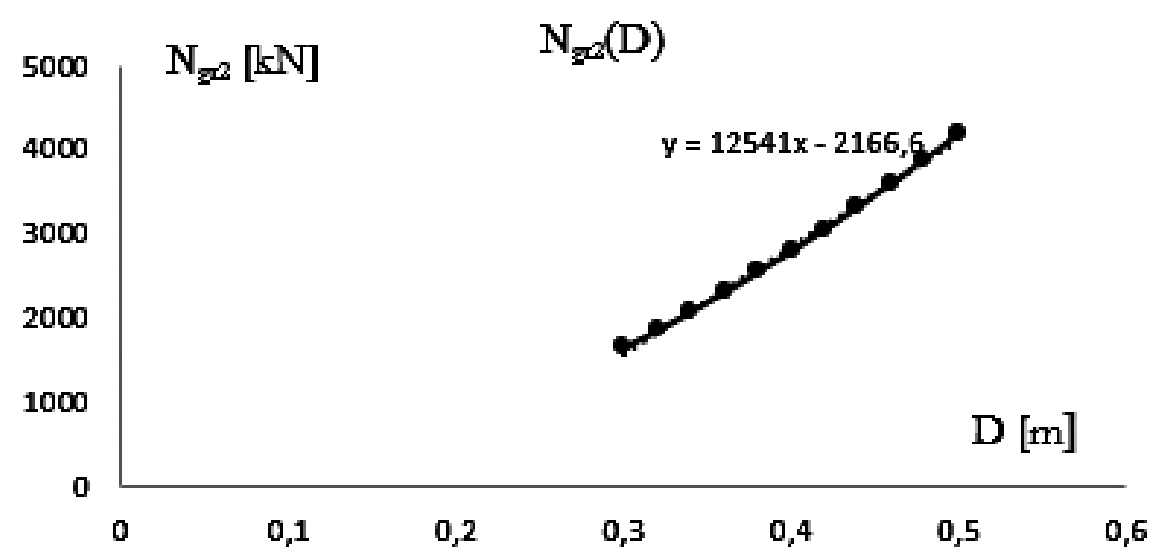

FIGURE 7. Graph presenting change of the load capacity $N_{g r 2}$ depending on the change of diameter $(D)$ 
TABLE 3. Change of the settlement $(s)$ depending on the change of diameter $(D)$

\begin{tabular}{|c|c|c|c|c|c|c|c|c|c|c|c|}
\hline$s(\mathrm{~m})$ & 0.01 & 0.01 & 0.011 & 0.012 & 0.012 & 0.013 & 0.014 & 0.014 & 0.015 & 0.016 & 0.016 \\
\hline$D(\mathrm{~m})$ & 0.3 & 0.32 & 0.34 & 0.36 & 0.38 & 0.4 & 0.42 & 0.44 & 0.46 & 0.48 & 0.5 \\
\hline
\end{tabular}

TABLE 4. Change of the load capacity $N_{g r 2}$ depending on the change of settlement $(s)$

\begin{tabular}{|c|c|c|c|c|c|c|c|c|c|c|c|}
\hline$N_{g r 2}(\mathrm{kN})$ & 1671 & 1876 & 2092 & 2318 & 2554 & 2800 & 3056 & 3322 & 3598 & 3883 & 4178 \\
\hline$s(\mathrm{~m})$ & 0.01 & 0.01 & 0.011 & 0.012 & 0.012 & 0.013 & 0.014 & 0.014 & 0.015 & 0.016 & 0.016 \\
\hline
\end{tabular}

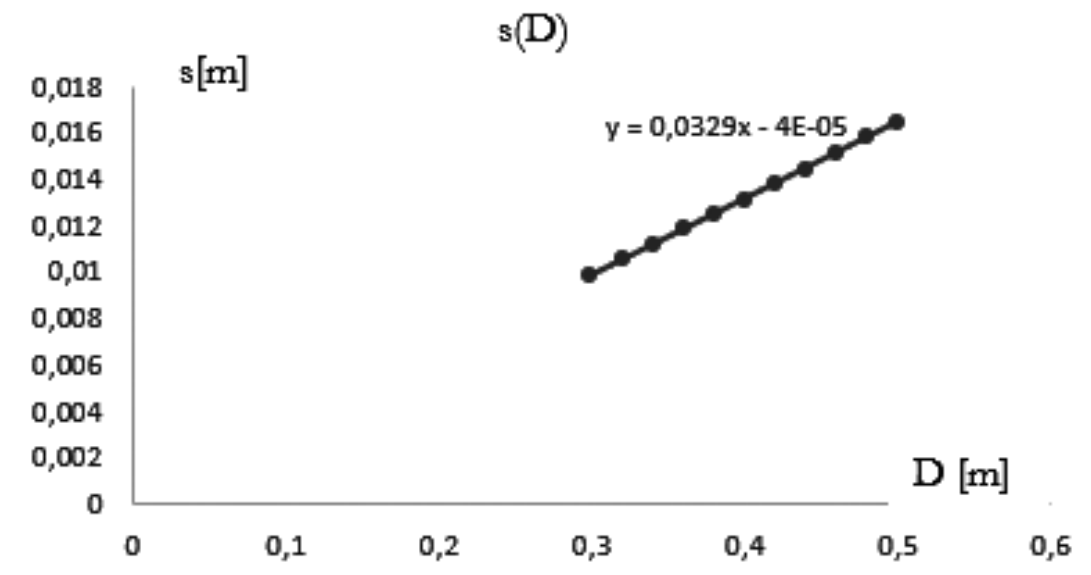

FIGURE 8. Graph presenting change of the settlement $(s)$ depending on the change of diameter $(D)$

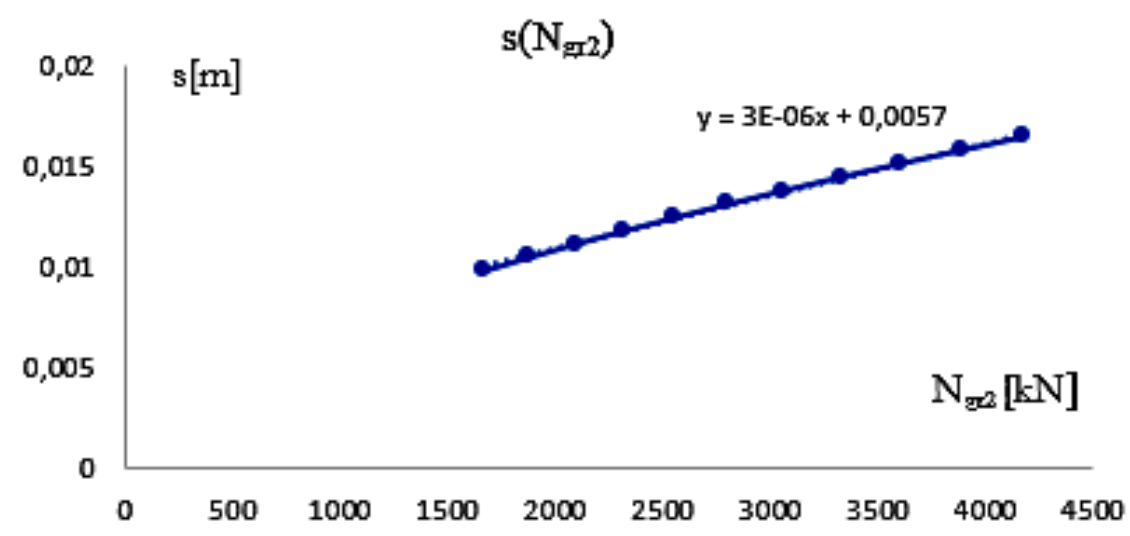

FIGURE 9. Graph presenting change of the load capacity $N_{g r 2}$ depending on the change of settlement $(s)$ 


\section{CONCLUSIONS}

1. In this work authors analysed possibility of determining static load tests curve in case of a diameter changes, using static load curve obtained from static load tests.

2. The analysis was based on a model proposed by Meyer and Kowalów (2010), where settlement curve is described by formulas (3)-(5).

3. Authorspreparedmathematicaldescription of phenomenon and according to it create a calculation program, which allows for a computer analysis.

4. Authors presented simulation calculation for a piles with a diameter form 0.3 to $0.5 \mathrm{~m}$ and $16 \mathrm{~m}$ length, which allow to estimate influence of a diameter changes on values of a limit load capacity $N_{g r 2}$ and settlement. Increase of diameter rise the value of a limit load capacity and also rise the value of a limit settlement. Changes can be approximately described as linear.

5. Authors presented example of obtaining load curves $N_{1}(s) ; N_{2}(s) ; T(s)$ for a pile with changed diameter, in relation to a pile subjected to static load test.

6. Program of further research includes using this method for analysing pile interaction with ground for layered soil.

\section{REFERENCES}

GWIZDAŁA K. 2010: Fundamenty palowe [Pile foundations]. Wydawnictwo Naukowe PWN, Warszawa.

MEYER Z. 2010: Analiza naprężeń na pobocznicy pala oraz pod podstawą pojedynczego pala w oparciu o liniową teorię Boussinesqa [Analysis of stresses on the pile skin and toe according to the Boussinesq linear theory]. XVIII
Seminarium Naukowe Regionalne Problemy Inżynierii Środowiska. Wydawnictwo Zachodniopomorskiego Uniwersytetu Technologicznego w Szczecinie, Szczecin.

MEYER Z. 2017: Wykorzystanie testu statycznego do prognozy osiadania, mobilizacji podstawy i pobocznicy [The use of a static load test to predict settelment, mobilization of pile skin and toe]. Warsztaty Pracy Projektanta Konstrukcji. Polski Związek Inżynierów i Techników Budownictwa, Warszawa.

MEYER Z., KOWALÓW M. 2010: Model krzywej aproksymującej wyniki testów statycznych pali [Model of a curve aproximating results of static load test]. Inż. Mor. Geotech. 3: 438-441.

MEYER Z., SZMECHEL G. 2015: Problemy zasad wymiarowania pali [Problems of piles dimensioning]. Inż. Mor. Geotech. 3: 444-449.

MEYER Z., ŻARKIEWICZ K. 2015: Analiza mobilizacji oporu pobocznicy i podstawy pala na podstawie interpretacji badań modelowych [Analysis of toe resistance and skin resistance based on the interpretation of model tests]. Inż. Mor. Geotech. 3: 350-354.

SZMECHEL G. 2014: Określenie nośności granicznej pali na podstawie próbnych obciążeń statycznych w ograniczonym zakresie. Rozprawa doktorska [Determination of the load carrying capacity of piles based on static load tests with limited load range]. PhD thesis, Zachodniopomorski Uniwersytet Technologiczny w Szczecinie.

ŻARKIEWICZ K. 2017: Analiza formowania się oporu pobocznicy pala $\mathrm{w}$ gruntach niespoistych na podstawie modelowych badań laboratoryjnych [Analysis of the formation of toe resistance and skin resistance in non-cohesive soils based on laboratory tests]. PhD thesis, Zachodniopomorski Uniwersytet Technologiczny w Szczecinie.

Streszczenie: Konwersja krzywej próbnego obciążenia statycznego (Q-s) w przypadku zmiany średnicy. $\mathrm{W}$ pracy przeanalizowano możliwość uzyskania krzywej statycznego, próbnego obciążenia pala przy zmianie średnicy, wykorzystując krzywą statycznego próbnego obciążenia pala uzyskaną na podstawie wyników badań dla zadanej średnicy. W analizie obliczeniowej wykorzystano metodę Meyera-Kowalówa (M-K). Poka- 
zano matematyczny opis możliwości stworzenia nowej krzywej M-K przy zmianie wymiarów pala, biorąc za podstawę pierwotną krzywą M-K uzyskaną z badań statycznych. Następnie przedstawiono przykład obliczeniowy, w którym wyliczono parametry modelu M-K dla nowej krzywej. W autorskim programie komputerowym przeprowadzono obliczenia symulacyjne, których wynikami są krzywe obciążenia dla pali o różnych średnicach oraz związki między zmianą średnicy a nośnością graniczną oraz osiadaniem pala.

Słowa kluczowe: pale fundamentowe, interpretacja krzywej obciążenia statycznego, nośność graniczna pala, osiadanie pala, metoda $\mathrm{M}-\mathrm{K}$
$M S$ received 16.01.2018

MS accepted 04.06.2018

\section{Authors' adresses:}

Zygmunt Meyer, Kamil Stachecki

Katedra Geotechniki

Wydział Budownictwa i Architektury

Zachodniopomorski Uniwersytet Technologiczny w Szczecinie

al. Piastów 50, 70-311 Szczecin

Poland

e-mail: meyer@zut.edu.pl

kmstachecki@gmail.com 